\title{
The Influence of the Holy Quran on Sheikh Kazem Al-Ozri Book of Poem
}

Mohammad Reza Abedi

\author{
PhD student,Department of Arabic Language and Literature, University of Lorestan
}

\section{Dr. Ali Nazari}

Associate Professor, Department of Arabic Language and Literature University of Lorestan (Author for Correspondence)

\section{Dr. Seyed Mahmoud Mirzaee Al-Hosseini}

Assistant Professor, Department of Arabic Language and Literature, University of Lorestan

\author{
Doi:10.5901/mjss.2016.v7n3s2p134
}

\section{Abstract}

Quran since the advent has been of interest to all human beings as a holy script. Poets benefited from it in creating their works of poetry given a special boom to them. Sheikh Kazem Al-Ozri Baghdadi (1143-1213 AH) is a committed poet with a lot of interest in the holy script in composing his book of poems. In this article we examine the influence of the Holy Quran, on the basis of technical and artistic intertextual relationship in terms of inspiration, the perfect combination, and modification, referential and stylistic using a descriptive adaptive method.

Keywords: Kazem, Al-Ozri, Quran, influence, intertextuality.

\section{Introduction}

Intertextuality is a critique term that was created first by Julia Kristeva in West literature (Kristeva, 2002: 27). She believed that "any text is constructed as a mosaic of quotes and each text is as the absorption and transformation of another text" (Kristeva, 2002: 44). In her opinion, there is no inherent text; that is, intertextuality that is composed of countless other texts it existence determined only through communication with other texts (Alghzami, 1990:131).

Intertextual term cannot be defined in one or more sentences, but Mohamed Meftah can be defined the most concise definition outlined that says "intertextuality is the interaction between diverse texts in different qualities and quantities" (Meftah, 1986, p. 121). Intertextuality, leads us to call for earlier texts because "any text gives meaning based on the literature we've already read that and is based on coding we have already known. Intertextuality draws our attention to previous texts. According to the intertextuality rule, every text has meaning only because we have earlier read texts "(Ahmad, 1999: 327).

Kristeva, entered the terms of the present text and hidden text into the intertextual discussion. The current text is called the present text and the texts to interact the present text are called absent text (Mosa, 2000: 51-52). And most important factor in intertextual relationship is the relationship between the two texts and this relationship gives meaning to a finds a new text to be due to old or contemporary texts (See: Mokhtari et al., 2010: 198). So, there are three pillars in an intertextual, which are:

1- Present text (hypertext): that is a subsequent text or the present text.

2- Absent text (hypotext), that is a former or missing text.

3- Intertextual relations that show the interaction between present text and absent text and the way they communicate (Friday, 2003: 128).

Intertextual relations are classified on the basis of the form absent texts in the present context, attitude and angle to look at the present text and compare it with the absent text. The following classifications are presented: 1) conscious and unconscious, 2) internal and external, 3) overt and covert, 4) parallel and reverse, 5) based on the absent text subject, 6) technical and artistic, that is several types: perfect text, perfect modification, stylistic, lexical, inspirational, referential, partial, multilateral and ... (Azzam, 2001:31; Halabi, 2007: 62 -80 ; Meftah, 1986: 119 -135; Khazali, 2009:64).

The Holy Quran as a written and enduring miracle challenges all human beings and is not exclusive to the time, 
place and not specific to individuals and has been of interest of all human since the advent. Raghib Isfahani, knows Quran the most precious words of Arab and a reference in obtaining provisions and shelter scholars and poets and eloquent man on proficient prose and verse (Esfahani ()AH, 1412: 6). Other scholars, including Suyuti know Quran as the source of various sciences that any technical, including strenuous refer to (Suyuti 1973: 2). Poets, has always been trying to use the Quran to the different purposes to their poetry since the advent of Islam and have given value and price to their works. Every poet, to allocate a greater share in this book is more present in the minds of the community, because, in addition to the special holiness of the Quran, Muslims are familiar with orders and decrees of life and the community events, with Quranic concepts, terms and texts. Sheikh Kazem Al-Ozri is one of the poets made abundance use of Holy Quran in their poetry and his poetry is whispered on the current literature, though died for more than two hundred years ago.

\section{Objectives}

This article aims to study the influence of Quran on Sheikh Kazem Al-Ozri book of poem contents on the basis of technical and artistic intertextual relationship.

Research questions:

A- To what extent Sheikh Kazem Al-Ozri poem is influenced by Quran?

B- Which mechanism affected Sheikh Al-Ozri poetry influenced by Quran?

\section{Hypotheses}

A- Sheikh Kazem Al-Ozri has been influenced by Quran at different levels.

B- Quran influence on Sheikh Kazem Al-Ozri poetry is reflected on intertextual relationship mechanism.

\section{Literature Review}

There are few studies on Sheikh Kazem Al-Ozri Baghdadi poems, including: 1) an essay entitled "The life and poetry of Sheikh Kazem Al-Ozri" by Ali Mirlohi (1976); 2) A master thesis entitled "descriptions and reviews and translations of a choice of ode by Sheikh Kazem Al-Ozri Baghdadi" by Issa Rezai (2002); 3) Master's thesis entitled "Prophets family in the mirror of Al-Ozri lyrics", by Farhad Rajabi Nowshadi (1995); 4) Master thesis entitled "Translation and subject description of 140 lines by Sheikh Mohammed Kazem Al-Ozri and syntactic and rhetorical issues (from line 176 to line315)", Ramin Zamiri (2012); 5) master thesis "Imam Hussein moan in Sheikh Mohammed Kazem Al-Ozri poems" by Leila Alai (2013); 6) Master thesis, entitled "Al-Zahra (PBUH) in contemporary Iraq poetry (Al-Ozri, Kashif Ghita, Waeli, Alqazvini, Alhaj Mohammad Ali al-Hallaq)" by Ilham Aghadoosti (2009). The author of this article could not find any article concerning the effect of Quran on Sheikh Al-Ozrio poetry. This paper tries to investigate different levels of effect of Quran text on Sheikh Kazem Al-Ozri poetry on the basis of technical and artistic intertextual relationship with an emphasis on crosscomparative method based on the above assumptions.

Sheikh Al-Ozri biography:

Kazem Al-Ozri, who some called him "Sheikh Kazem", some "Mulla Kazem" and "Mohammed Kazem Al-Ozri ". He had the position of special honor among two prominent Clergymen and rulers of his time, respectively. He was born in Baghdad's neighborhood of Ras Al-qrieh in a famous, wealthy and elite family in the year $1143 \mathrm{AH}$; he was not able to walk until the age of seven, but then walked. He spent time in studying science in Najaf at presence of great masters. He was very discerning and shrewd with strong memory. He started composing poetry at the age of seventeen. He had extensive information on the areas of jurisprudence, religious principles, history, exegesis, hadith and philosophy; he was so clear in the context of his religious expression that was forced to always carry a gun for the fear of enemies. He passed away in about seventy between the years 1211 to $1213 \mathrm{AH}$, in the Karkh district of Baghdad (see: Qomi, dateless: 2/19, Tehran, 1408 AH, 9/69; Herz Al-Din, 1405 AH: 2/161; Sheber, dateless: 26-37; Herz Al-Din, 1992: 1/138; Zarkli, 1980: 5/215; Amin, 1421 AH, 1421:43/101; Kahaleh, 1993:20; Modaresi Tabrizi, 1995: 1 / 110-111). Sheikh Kazem is a committed poet. His love to Quran has made his poems flavored by the Quranic concepts. There is no ode without the Quranic concept in his poems.

Intertextuality in Sheikh Kazem Al-Ozri poetry

Inspirational intertextuality from Holy Quran is the most frequent type of intertextuality by Sheikh Al-Ozri.

Conceptual and inspirational intertextuality relationship:

In this type of intertextual relationship, the poet gains the theme of his statement from a concept or a notion and 
processing takes place in such a way that the reader who is aware of the absent text understands the conceptual link between the hypotext and hypertext content. In the Quran, the inspiration sometimes is from several verses or a verse or part of the verse. In this case, there is no explicit reference to the absent text (Tuma, 2007: 72-73).

Quran (absent text - pre text):

"Evil women for evil men, and evil men for evil women; good women for good men, and good men for good women these are clear of what has been said; for them is forgiveness, and a generous provision" (Al-noor: 26)

The book of poem (present text - post text)

"What good things and act only for the people / and you thank God is the best delicacies" (Al-Ozri: 1980: 107) to him.

Poet in praise of Solomon Bey Shavian (1794-1209 AH) inspired by the verse above, attributed the decent works

"Good land yields its vegetation by the permission of its lord. while the corrupted yields only the scanty. so we make plain the verses to those who are thankful" (Al-araf: 58).

The book of poem (present text - post text)

The land if brought out its soil yields/ germinated the best of what is and exhilarating (Al-Ozri: 1980: 116)

If wasted well, it is wonderful / Maybe missed a drop and gained a pool (Al-Ozri, 1980:127)

Poet in praise of Solomon Bey Shavian and criticism of his enemies inspired by the following verse resembles him to fertile ground, namely a noble and pure heart human nature and resembles his enemies to a barren desert, namely indecent humans.

"Do not turn your cheek in scorn away from people, nor walk proudly on the earth; allah does not love the proud and the boastful (Luqman: 18)

The book of poem (present text - post text)

And you didn't gain the kingdom of beauty, be honest / the benevolent is not striking for his nose (Al-Ozri, 1980:125).

Poet, at the beginning of the ode in praise of Solomon Bey Shavian, has approached the words in the former poet's style with Sonnet. And inspired by the above verse and the words "Shmkh Banfh" which alludes to the arrogance and synonymous with the verses, demand attention of praised. The verse is serious with objective advice, but the poet used it as humor, to draw attention of praised to eulogy and achieve the desired praise.

Combined perfect intertextuality:

This type of intertextual relationship is based on the full and independent text and the original text is used by the creator exactly intact without increasing or addition in its original context of the present text (Post text), whether it is a line of text or a poem or prose sentence "(Halabi: 2007, 61). This type of intertextual relationship is in fact the adoption and guarantee without mentioning the reference word or phrase that is taken from the Quran, poetry, prose or any other work, with no change or very small amount of change with objectives such as: enrichment of word, blessing, explaining, arguing, metaphor, deter, decorations, citations, etc. placed in the word (Rastgo: 2006, 30).

Without any transformation:

Quran (absent text - pre text):

The statement "Keaia Yasha" is used several times in Quran, for example:

The book of poems (present text- post text)

Poet, in an ode to praise Asaad Effendi Fakhrizadeh (1203 AH) established full text relationship with a Quranic phrase "Keaia Yasha"

Small changes:

It is noteworthy that some minor changes are permissible in the condition does not prejudice structure of semantic and conceptual brokerage the word. Sheikh Kazem Ozri has used this type of intertextual relationship -also in some cases-although relatively low.

Quran (absent text- pre text):

"And say, "exaltations be to our lord! the promise of our lord is done" (Al-ISRA: 108) 
Quranic phrase " the promise of our lord is done " is used in verse with slight changes. Poet in praise of Solomon Shavian, has brought the complete textual relationship with little change in the text of the Quran which no semantic structure and conceptual change.

The book of poems (present text- post text)

It is the promise of old glorious / his promised was always fulfilled (Al-Ozri, 1980:350).

Adjusted complete intertextual relationship:

In this type of relationship, the poet relies on independent and full text (either a line of prose or a poem or phrase). He has separated the text and after some deconstructs simple or complex, such as addition or deletion, prioritizing or deterioration of the components, change in tense and voice, statements to affirmative and so forth creates his poetic text to express ideas (Halbi, 2007: 64).

Quran (absent text- pre text)

"Many a small band has, by the permission of allah, vanquished a mighty army. allah is with the patient. "' (Al-Baqarah: 249)

The book of poems (present text- post text)

How small band to be supported / won over big numbers fully overwhelmed (Al-Ozri, 1980: 68)

The poet has used all the verse with some changes. The call is informed with the objective to praise Solomon Pasha (1217 AH), which has achieved.

Quran (absent text- pre text)

"Or those who disbelieve, the worldly life is decked with all manner of decorations. they scoff at those who believe, but the cautious shall be above them on the day of resurrection. Allah gives without count to whom he will" (Al-Baqarah: 212)

The book of poems (present text- post text)

Did not stay prefer, however, earned it / Glory of giving without the expense (Al-Ozri, 1980: 92)

The phrase "Allah gives without count to whom he will"is used in several other verses and the poet has used it in his poems in the same way with some changes. The call is informed with the objective to praise Solomon Pasha, which has achieved

The poet has used part of verse with changes in his poem. The poet has used all the verse with some changes. The call is informed with the objective to praise Solomon Pasha (1217 AH), which has achieved. Also, refers to the following verse in elegance:

"When your lord brought forth descendants from the loins of adam's children, and made them testify concerning themselves (he said): 'am i not your lord.' they replied: 'we bear witness (that you are). 'lest you should say on the day of resurrection: 'we had no knowledge of this (Al-Araf: 172)

Inferential intertextual relationship (allusion):

In this type of relationship, the poet's puts his words, based on the story or event or the point of the hypotext (absent text) and just to mention one or more hints that leads the reader to the absent text, so that little words transfer many meanings to the reader (Halabi, 2007:68; Rastgo, 2006: 52). The peculiarity of this type is brevity and collected many meanings in few words (Halabi, 2007:68). Sheikh Kazem Al-Ozri has benefited from this intertextual practice in recalling events and issues raised in the Quran, although in minimum.

Sheikh Kazem Al-Ozri sometimes referred to, in the form of calling a character by the name and applies it to most frequent name-Solomon-and because the name of two praised persons are Solomon.

This is the time Solomon that guidance of the west and east is at his hand.

The King when points with his ring, the toughest rogue rulers obey him.

The King when Mill fails makes it circulate with his finger. (Al-Ozri, 1980: 476)

Poet, recalls Solomon, the prophet, in praise of Solomon Shavian. Calling Solomon's character in this ode takes two forms, one recalled his name, and the other to call the praised to run the country with full authority and it does not actually matter that no one dare to disobey him. He has picked up this call from the Holy Quran and brings us to it with 
some implications. The first reference to the name of Solomon is to his rule. In the second verse refers to the ring of Solomon and obeying all creatures, even the most ardent of his enemies at his wills (See, Tabarsi, 1993: 8/743) and the third line refers to the ability to perform the most difficult tasks because of his God bestown ability, so that demonstrated the praiseworthy authority.

Holy Quran: in the verses (Saba / 12), (Al-anbiya / 81), (Al-namal / 17) as well as (Al-baqrah / 102).

Referential words: Solomon, Khatam

Sometimes the referential words are calling the Quran using the title character and the story is inferred. He leads to Mosa using the words "Tor Altajala" and "kalim" in the following lines:

And for me over the mountain, lighting up the fire that injured thirst for optimal (answer the echo of Mosa).

The poet's in an ode where Suleiman Beg Shavian is praised, recalls Mosa which deals with his wife out of Midian, and was lost in the darkness of a cold winter night. Lamp was not clear when his wife was giving birth, he sees a light and tells his wife to wait a moment, and I see a fire, leaving it to bring fuel of the light, or to see someone there for help. Once the fire comes close, with surprise that the fire engulfed the whole tree, but trees and beautiful green are in white fire, where fire and vegetable stands and he was watching the beauty of the tree. At this time the tree calls: O Moses! I am your Creator and your affairs are at my hands. (See: Tabarsi, 1993: 7 / 7-8; Zamakhshri, 1407 AH: 3/ 53-55). It is here that Mosesnot only get rid of confusion, but also gains prophecy and divine revelation. In this way, in fact, the praised is asked to get rid of confusion and raise their demands.

Holy Quran (TaHa / 9-14), (Alqesas / 29) as well as (Alqesas / 46).

Referential words: Nar- Tor- Tajali- Kalim - Anast- Qabs

My heart was so obedient that if was not love, his disobedience was as long stick of Moses- obedience. (Al-Ozri, 1980: 328)

Sometimes called a reference to the character and story by referring to the miracles of the Qur'an:

O Allah! Some of them are doctor guaranteed healing every hardly disease. With his courage and good tidings to any gift have been sent to the people. (Al-Ozri, 1980: 363)

Poem is an ode in praise of Abdullah Bey Shabby. He uses Jesus Miracles to rise up the praised referring to miracle of curing incurable patients in the first line and the good news to come prophet after him.

Quran verses (Al-Imran / 49) and (Alsaf / 6) referred to it in full.

Healed incurables by Jesus are in verse 110 of Al-Maedia Surah.

Referential words: Ateba- Mobasherin- Monzerin.

\section{Conclusion}

After examining Sheikh Kazem Al-Ozri books of poem, the following results were obtained:

1. Sheikh Kazem has benefited from technical and artistic intertextual relations with the Holy Quran at various levels of his poems.

2. The most frequently used mechanism in the intertextual relationship is the mechanism of inspirational intertextual relationship.

3. He has established intertextual relationships with a wide range of traditions, proverbs and poems.

4. He is well familiar with meanings and interpretations of Quran.

5. He has shown sacrifice in defense of their faith and Imamate.

\section{References}

Holy Quran

Ahmadi, Babak, (2008), "the structure and interpretation of the text", Markaz pub, Tehran

Al-Ozri, Kazem, (1980), "The book of poems", Research by Shakir Hadi Shakir, DarAltojih Al-Islami, Beirut.

Amin Ameli, Seyed Mohsen (1421 AH), "Aayan Al-Shia", Beirut, Daraltarf.

Tehrani, Sheikh Aqa Bozorg (1408 AH), "Alzariaa ela tasanif al-shia", parts, Qom Ismailis and Tehran Islamiyah library, Iran.

Jome, Hossein (2003), "Almesbar fi Alnaqd Adabi", Etehad Kitab al-Arab, Beirut.

Herz Al- Din, M. (1371 AH), "Knowledge of shrines in the appointment of the Alawites and the companions and followers, narrators, scientists, writers and poets graves", research by: Mohammed Hussein al-Sheikh Ali Herz Al- Din, Saeed bin Jabir publishing.

Herz Al- Din Mohammad Hossein ibn Ali (1405 AH), "Maaref Al-Rejal", Marashi Najafi library, Qom.

Raghib Isfahani, Hussein ibn Muhammad (1412 AH), "Almofradat Fi Gharib Al-Qoran, research by: Safwan Adnan Daoudi, Dar al Alm 
daralshamieh, Damascus / Beirut.

Zamakhshari Mahmud, (1407 AH), "Alkashef an haqayeq qavamez altanzil", Daralktab Arabi, Beirut.

Suyuti, Jalal al-Din (1973), Alatqan fi Ulom Al-Qouran, Al-Maktab Alsaqafieh, Beirut, Lebanon.

Tabarsi Fazl ibn Hasan (1993), "Majam Al Bayan Fi Tafsir Al-Qouran", Naser Kosro Publication, Tehran.

Azzam, Mohamad,(2001), "Alnas Alghaeb (manifestations of Altnas in Arabic poetry), Etehad Alketab Publication, Damascus.

Azavi, Abbas (1996), "the history of Arabic literature in Iraq, Imad Abdul Al-salam Rauf", the ministry of culture.

Alghazami, Abdulla, (1986), "Alkhtiah va Altafkir men Albanoieh ella Altashrihiye, Almarkz Alsaqafi Alarabi”, Daralbeiza, Morroco.

Qomi, Sheikh Abbas (dateless), "Alkane va Alalqab, Beirut, anonymous.

Kristeva, Julia (2002), "the conversation word of novel, the postmodernist, post-structuralist in literary studies", translated by: Payam Yazdanjoo, Tehran, Markaz pub.

Kahaleh, Omar Reza, (1993-1414 AH), "Mu'jam Al-moalefin, Alrsalh Institute.

Modares Tabrizi, Mohammad Ali (1995), "Reyhant Al-adb fi Tarajem Almarofin Belkonieh Vallqb ya Konye va Alqab", Heydari Publishing, Tehran.

Meftah Mohammad, (1990), "Tahlil Al-Khattab Alsheari (Astrtajieh Al-tanas), Al-Arabic culture center, Dar Al-Bayda, Morocco.

Mousa, Khalil (2000), "Qeraat Fi Shear Al-Hadith Al-maaser", Etehad Alketab Publication, Beirut.

\section{Articles}

Halabi, Ahmad Tuma (2007), "Ashkal Altanas Alsheri Sheralbayati Nemozja" Almvqf Aladbyh Journal, No. 430, pp. 62-80.

Khazali, Ensiah (2009), " Altanas Al-Daini fi Adab Lebanese Almasr", Ulum Alansanyh international journal, No. 16, pp. 61-89.

Mokhtari, Kassim \& Qolamreza Shanegh (2010) "Quranic and narrative intertextuality in Seyed Hemyari poetry ", Journal of Lesan Mobin, Second Year, pp: 197-215. 